\title{
Chemical constituents from Munronia sinica and their bioactivities
}

\author{
Xiao-Li Li, ${ }^{\mathrm{a}, \mathrm{b}, *}$ Qiu-Xia He, ${ }^{\mathrm{c}}$ Feng-Lei Zhang, ${ }^{\mathrm{d}}{ }^{\text {Yan-Li ZhaO, }}{ }^{\mathrm{a}, \mathrm{b}} \mathrm{Ke}$-Chun LiU, ${ }^{\mathrm{c}}$ and Si-Ping JiAnG ${ }^{\mathrm{e}}$ \\ ${ }^{a}$ Key Laboratory of Economic Plants and Biotechnology, Kunming Institute of Botany, Chinese Academy of Sciences, \\ Kunming 650201, China \\ ${ }^{\mathrm{b}}$ State Institute of Tibetan Plateau Research at Kunming, Kunming Institute of Botany, Chinese Academy of Sciences, \\ Kunming 650201, China \\ ${ }^{\mathrm{c}}$ Biology Institute of Shandong Academy of Sciences, Jinan 250014, China \\ ${ }^{\mathrm{d}}$ Kunming City Institute of Materia Medica, Kunming 650051, China \\ ePlateau Institute of Biology, Lhasa 850000, China
}

Received 1 January 2012; Accepted 16 March 2012

(C) The Author(s) 2012. This article is published with open access at Springerlink.com

\begin{abstract}
Two new minor constituents, musinisins A (1) and B (2), together with five known compounds (3-7), were isolated from the aerial parts of Munronia sinica. Their structures were established by means of spectroscopic methods and the absolute stereochemistry of $\mathbf{1}$ was determined by single crystal X-ray experiment. Compound $\mathbf{4}$ showed antiangiogenic activity evaluated by a zebrafish model and apoptosis-inducing effect on A549 lung cancer cells.
\end{abstract}

Keywords: Munronia sinica, chemical constituent, musinisin, antiangiogenic activity

\section{Introduction}

The genus of Munronia (Meliaceae) is composed of about 15 species in the world, and 8 species of them were distributed in China. ${ }^{1}$ Up to now, some phytochemical studies have been reported on $M$. delavayi ${ }^{2-5}$ and $M$. henryi ${ }^{6-9}$, and tetranortriterpenoids and triterpenoids are their main components. Especially, tetranortriterpenoids exhibit chemical defensive function in nature, such as antibacterium, antifungal, ${ }^{2}$ and antifeeding ${ }^{8}$ activities. M. sinica Diels grows in Jinfoshan of Sichuan, which is low subshrubs and an endemic species of China. To the date, no chemical research has been published about this species. In this paper, we reported the isolation and structure elucidation of two new compounds, musinisins A (1) and B (2), together with five known compounds, including glucoacetosyringone $(\mathbf{3}),{ }^{10} 6,7$ bis(acetyloxy)-4,4,8-trimethyl-3-oxo-(5 $\alpha, 6 \alpha, 7 \alpha, 13 \alpha, 17 \alpha, 20 \xi)$ carda-1,14-dienolide (4), ${ }^{11}$ cannabiside D (5), ${ }^{12}$ corchoionoside C $(6),{ }^{13}(+)$-3-oxo- $\alpha$-ionyl glucoside (7). ${ }^{14}$ Compounds 1-7 were tested for their antiangiogenic activities using a zebrafish model and the antiproliferative activities using A549 lung cancer cells.

\section{Results and Discussion}

A $70 \%$ aqueous acetone extract prepared from the leaves

*To whom correspondence should be addressed. E-mail: li_xiaoli11@mail.kib.ac.cn<smiles>CC(C)=C(C)C(=O)OC1OC(CO)C(O)C(O)C1O</smiles><smiles>COc1cc(C(C)=O)cc(OC)c1OC1OC(CO)C(O)C(O)C1O</smiles>

3<smiles>COc1cc([C@@H](C)O)cc(OC)c1OC1OC(CO)C(O)C(O)C1O</smiles>

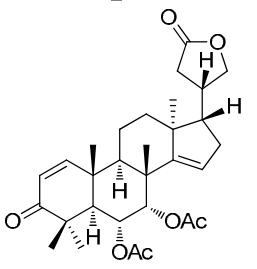

4<smiles>CC(=O)C1=CC2=C(C)C(O)CC(OC3OC(CO)C(O)C(O)C3O)CC2C1</smiles>

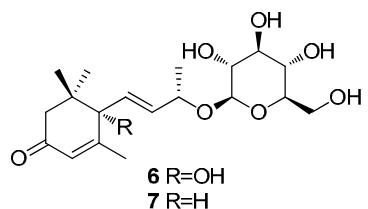

Figure 1. The structures of compounds 1-7

and stems of $M$. sinica was partitioned between EtOAc and $\mathrm{H}_{2} \mathrm{O}$. The EtOAc layer was subjected repeatedly to column chromatography on silica gel, Sephadex LH-20, and RP-18, to afford compounds 1-7. Their structures were shown in Figure 1 , and ${ }^{1} \mathrm{H}$ and ${ }^{13} \mathrm{C}$ NMR spectroscopic data were listed in Tables 1 and 2 . 
Table 1. The NMR (DMSO- $d_{6}, \delta$ in ppm, $J$ in Hz) data of 1

\begin{tabular}{cllccc}
\hline position & $\delta_{\mathrm{C}}$ & \multicolumn{1}{c}{$\delta_{\mathrm{H}}$} & position & $\delta_{\mathrm{C}}$ & $\delta_{\mathrm{H}}$ \\
\hline 1 & $175.7 \mathrm{C}$ & & $3^{\prime}$ & $18.1 \mathrm{CH}_{3}$ & $0.79(\mathrm{~d}, 6.6)$ \\
$2 \mathrm{a}$ & $31.3 \mathrm{CH}_{2}$ & $2.28(\mathrm{dd}, 16.2,5.7)$ & $\mathrm{Glc}$ & & \\
$2 \mathrm{~b}$ & & $2.03(\mathrm{dd}, 16.2,5.9)$ & $1^{\prime \prime}$ & $102.8 \mathrm{CH}$ & $4.13(\mathrm{~d}, 7.8)$ \\
3 & $44.7 \mathrm{CH}$ & $1.87(\mathrm{~m})$ & $2 "$ & $73.9 \mathrm{CH}$ & $2.90(\mathrm{t}, 8.5)$ \\
4 & $75.9 \mathrm{CH}$ & $3.77(\mathrm{~m})$ & $3 "$ & $76.9 \mathrm{CH}$ & $3.08(\mathrm{~m})$ \\
5 & $21.4 \mathrm{CH}_{3}$ & $1.05(\mathrm{~d}, 6.6)$ & $4^{\prime \prime}$ & $70.3 \mathrm{CH}$ & $3.00(\mathrm{~m})$ \\
$i-\mathrm{pr}$ & & & $5 "$ & $76.9 \mathrm{CH}$ & $3.03(\mathrm{~m})$ \\
$1^{\prime}$ & $27.6 \mathrm{CH}^{\prime}$ & $1.78(\mathrm{~m})$ & $61.3 \mathrm{CH}_{2}$ & $3.63(\mathrm{br} . \mathrm{d}, 11.3)$ \\
$2^{\prime}$ & $19.4 \mathrm{CH}_{3}$ & $0.82(\mathrm{~d}, 6.7)$ & & & $3.40(\mathrm{dd}, 11.3,4.4)$ \\
\hline
\end{tabular}

Compound $\mathbf{1}$ was obtained as colorless crystals. Its molecular formula, $\mathrm{C}_{14} \mathrm{H}_{26} \mathrm{O}_{8}$, was established on the basis of HRESIMS analysis $\left([\mathrm{M}-\mathrm{H}]^{-}, m / z\right.$ 321.1543, calcd 321.1549) and its ${ }^{1} \mathrm{H}$ and ${ }^{13} \mathrm{C}$ NMR spectra. Analysis of the ${ }^{1} \mathrm{H}$ and ${ }^{13} \mathrm{C}$ NMR (Table 1), HSQC and HMBC spectra of 1 revealed the presence of 14 carbons, including one carboxylic acid group $\left(\delta_{\mathrm{C}} 175.7\right)$, one $i$-pr group $\left(\delta_{\mathrm{C}} 27.6,19.4,18.1\right)$, one methyl $\left(\delta_{\mathrm{C}}\right.$ $21.4)$, one methylene $\left(\delta_{\mathrm{C}} 31.3\right)$, two methines $\left(\delta_{\mathrm{C}} 44.7\right.$ and $75.9)$, and one hexose $\left(\delta_{\mathrm{C}} 102.8,76.9,76.9,73.9,70.3,61.3\right)$. In the ${ }^{1} \mathrm{H}-{ }^{1} \mathrm{H}$ COSY spectrum (Figure 2), the correlation of $\mathrm{H}-$ 2/H-3/H-4/Me-5 was observed, which established the direct connections of C-2, C-3, C-4 and C-5. The $i$-pr group locating at $\mathrm{C}-3\left(\delta_{\mathrm{C}} 44.7\right)$ was determined by the HMBC correlations of $\mathrm{H}-3\left(\delta_{\mathrm{H}} 1.87, \mathrm{~m}\right)$ with the carbon signals at $\delta_{\mathrm{C}} 27.6\left(\mathrm{C}-1^{\prime}\right)$ and 19.4 (C-2') of $i$-pr group and ${ }^{1} \mathrm{H}-{ }^{1} \mathrm{H}$ COSY correlation of $\mathrm{H}-3$ with $\mathrm{H}-1^{\prime}$ (Figure 2). The linkage position of the hexose

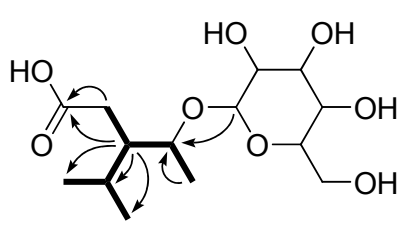

1

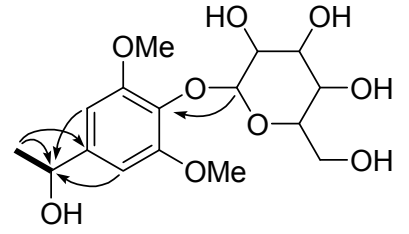

2
Figure 2. Key $\mathrm{HMBC}(\rightarrow)$ and ${ }^{1} \mathrm{H}^{-}{ }^{1} \mathrm{H} \operatorname{COSY}(-)$ correlations of $\mathbf{1}$ and $\mathbf{2}$

moiety was located at C-4 $\left(\delta_{\mathrm{C}} 75.9\right)$ of its aglycone by the HMBC correlations of the anomeric proton at $\delta_{\mathrm{H}} 4.13$ with C-4. The anomeric center of the sugar moiety was determined to be $\beta$-configuration from the large ${ }^{3} J_{\mathrm{H} 1^{\prime \prime}-\mathrm{H} 2^{\prime \prime}}$ value $(J=7.8 \mathrm{~Hz})$. Furthermore, we get a suitable crystal and the X-ray experiment was conducted using an anomalous dispersion with copper radiation (Figure 3), which not only determined the hexose to be D-glucose, but also established the absolute stereochemistry of $\mathbf{1}$. In combination with IUPAC sequence rule, ${ }^{15}$ the configuration of $\mathrm{C}-3$ and $\mathrm{C}-4$ were deduced as $R$ and $S$, respectively. Thus, the structure of $\mathbf{1}$ was established as $(3 R, 4 S)$-3-isopropyl-4-hydroxypentanoic acid $4-O-\beta$-D-glucopyranoside and given the name of musinisin A. The plausible biogenetic pathway of 1, starting from, 3-isopropyl-4methylcyclohexene was also discussed (Scheme 1).

Compound 2 was isolated as yellow powder with $[\alpha]_{\mathrm{D}}^{19.9}-$ 54.86 ( $c$ 0.14, MeOH). The molecular formula, $\mathrm{C}_{16} \mathrm{H}_{24} \mathrm{O}_{9}$, was deduced by HRESIMS ([M $+\mathrm{Cl}]^{-}$at $\mathrm{m} / \mathrm{z}$ 395.1100; calcd 395.1108), with five degrees of unsaturation. The ${ }^{1} \mathrm{H}$ NMR spectrum (Table 2) showed signals for two methoxyl groups. Comparison of the 1D and 2D NMR data of 2 with those of known compound glucoacetosyringone $(\mathbf{3})^{10}$ revealed that
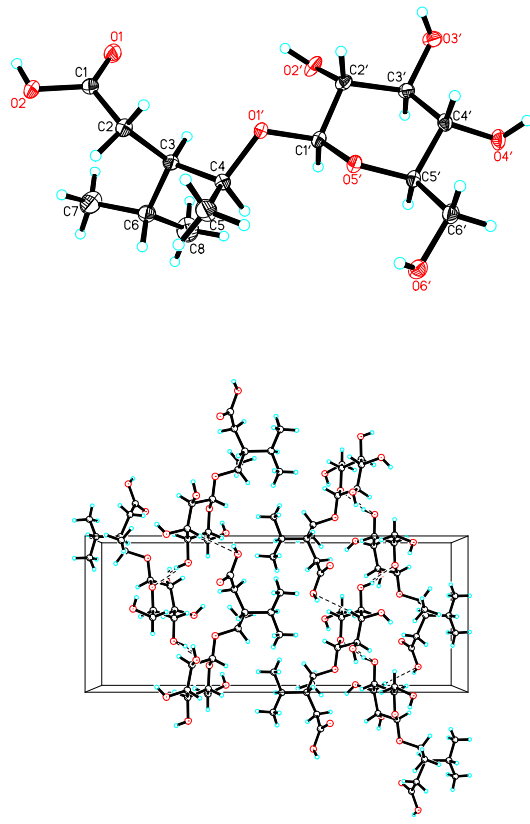

Figure 3. X-ray structure of 1 showing absolute configuration

compound $\mathbf{2}$ was structurally similar to $\mathbf{3}$. The differences were resulted from the appearance of an oxygenated methine signal $\left(\delta_{\mathrm{C}} 68.2, \mathrm{CH} ; \delta_{\mathrm{H}} 4.6, \mathrm{~m}\right)$, and the lack of a carbonyl signal in 2. This indicated that the carbonyl group at C-7 in 3 was replaced by an oxygenated methine group in 2 , which was confirmed by the HMBC correlations of H-2 $\left(\delta_{\mathrm{H}} 6.62\right)$, H-6 $\left(\delta_{\mathrm{H}} 6.62\right)$ and $\mathrm{Me}-8\left(\delta_{\mathrm{H}} 1.30\right)$ with $\mathrm{C}-7\left(\delta_{\mathrm{C}} 68.2\right)$ and the ${ }^{1} \mathrm{H}-{ }^{1} \mathrm{H}$ $\mathrm{COSY}$ correlation of H-7/Me-8 (Figure 2). Acid hydrolysis of $2(5 \mathrm{mg})$ in $2 \mathrm{M} \mathrm{HCl}(3 \mathrm{~mL})$ provided a D-glucose and an aglycone $\left(\mathrm{C}_{10} \mathrm{H}_{14} \mathrm{O}_{4}\right.$, an amorphous powder, $\left.[\alpha]_{\mathrm{D}}^{19.9}-4.63\right)$. The glycosyl group was detected by TLC comparison with authentic sample using $\mathrm{CHCl}_{3}-\mathrm{MeOH}(8: 2)$ as a developing system $\left(R_{f}=0.16\right)$. The anomeric center of the glucose moiety

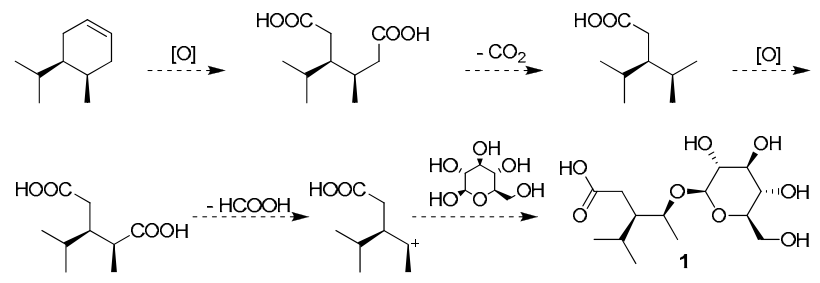

Scheme 1. Hypothetical biogenetic pathway of $\mathbf{1}$ 
Table 2. The NMR (100 MHz, DMSO- $d_{6}, \delta$ in ppm, $J$ in Hz) data of 2

\begin{tabular}{cccccc}
\hline position & $\delta_{\mathrm{C}}$ & \multicolumn{1}{c}{$\delta_{\mathrm{H}}$} & position & $\delta_{\mathrm{C}}$ & $\delta_{\mathrm{H}}$ \\
\hline 1 & $143.2 \mathrm{C}$ & & $\mathrm{Glc}$ & & \\
2 & $103.5 \mathrm{CH}$ & $6.62(\mathrm{~s})$ & $1^{\prime}$ & $102.9 \mathrm{CH}$ & $4.81(\mathrm{~d}, 7.3)$ \\
3 & $152.4 \mathrm{C}$ & & $2^{\prime}$ & $7.2 \mathrm{CH}$ & $3.19(\mathrm{~m})$ \\
4 & $133.1 \mathrm{C}$ & & $3^{\prime}$ & $76.5 \mathrm{CH}$ & $3.19(\mathrm{~m})$ \\
5 & $152.4 \mathrm{C}$ & $4^{\prime}$ & $70.0 \mathrm{CH}$ & $3.15(\mathrm{~m})$ \\
6 & $103.5 \mathrm{CH}$ & $6.62(\mathrm{~s})$ & $5^{\prime}$ & $77.2 \mathrm{CH}$ & $3.02(\mathrm{~m})$ \\
7 & $68.2 \mathrm{CH}$ & $4.63(\mathrm{~m})$ & $6^{\prime}$ & $61.0 \mathrm{CH}_{2}$ & $3.56(\mathrm{dd}, 11.5,5.9)$ \\
8 & $25.9 \mathrm{CH}_{3}$ & $1.30(\mathrm{~d}, 6.4)$ & & & $3.42(\mathrm{dd}, 11.5,5.9)$ \\
& & & $2 \times \mathrm{CH}_{3} \mathrm{O}$ & $56.4 \mathrm{CH}_{3}$ & $3.72(\mathrm{~s})$ \\
\hline
\end{tabular}

Table 3. Antiangiogenic activity of compounds $1,2,4,5$ and 7

\begin{tabular}{|c|c|c|c|c|}
\hline compound & concentration $(\mu \mathrm{g} / \mathrm{mL})$ & intersegmental vessels (ISV) & inhibition ratio (\%) & $\mathrm{IC}_{50}(\mu \mathrm{g} / \mathrm{mL})$ \\
\hline 1 & 100 & $17.9 \pm 3.8$ & 26.0 & \\
\hline 2 & 100 & $20.2 \pm 6.9$ & 16.5 & \\
\hline 4 & 40 & $10.0 \pm 6.6$ & 58.7 & 35.7 \\
\hline 5 & 60 & $17.1 \pm 8.8$ & 29.4 & 96.5 \\
\hline 7 & 100 & $22.8 \pm 2.3$ & 5.6 & \\
\hline control $^{\mathrm{a}}$ & & $24.2 \pm 2.0$ & & \\
\hline PTK787 & 10 & $0 * *$ & 100 & \\
\hline
\end{tabular}

${ }^{\mathrm{a}} 0.1 \%$ DMSO in sterile salt water; $* *$ means that the value was significantly different from the control and $p<0.01$.

was determined to be $\beta$-configuration from the large ${ }^{3} J_{\mathrm{H} 1^{\prime}-\mathrm{H} 2^{\prime}}$ value $(J=7.3 \mathrm{~Hz})$. As the aglycone showed a negative optical rotation value that was opposite to that of $(1 R)$-1-phenyl-1propanol, ${ }^{16}$ the absolute configuration at $\mathrm{C}-7$ of 2 was suggested to be $S$. Thus, the structure of $\mathbf{2}$ was established and given the trivial name musinisin $\mathrm{B}$.

The antiangiogenic activities of compounds $1,2,4,5$ and 7 were evaluated using a zebrafish model, in terms of the inhibition on the growth of intersegmental vessels, with PTK787 as positive control $\left(\mathrm{IC}_{50} 0.15 \mu \mathrm{g} / \mathrm{mL}\right) .{ }^{17}$ The results showed that intersegmental vessels of embryos treated with 4 was significantly less than that of the control $(0.1 \%$ DMSO in sterile salt water). The inhibition ratio of 4 was $58.7 \%$ at a concentration of $40 \mu \mathrm{g} / \mathrm{mL}$ (Table 3). The antiproliferative activities of compounds 1-7 were evaluated using A549 lung cancer cells by MTT assay. ${ }^{18}$ The results indicated that compounds 1, 2, 4 and 7 showed a certain extent antiproliferative activities (Table 4). From the photos of acridine orange staining, compound $\mathbf{4}$ showed obvious effect of inducing apoptosis of A549 lung cancer cells (Figure 4).

Table 4. Inhibitory effect of compounds $1,2,4$, and 7 on the proliferation of A549 lung cancer cells

\begin{tabular}{cc}
\hline \multirow{2}{*}{$\mathrm{M}(\%)^{\mathrm{a}}$} & concentration \\
\cline { 2 - 2 } compound & $50 \mu \mathrm{g} / \mathrm{mL}$ \\
$\mathbf{2}$ & $72.93 \pm 6.80^{* *}$ \\
$\mathbf{4}$ & $67.33 \pm 2.71^{* *}$ \\
$\mathbf{7}$ & $32.80 \pm 0.88^{* *}$ \\
\hline
\end{tabular}

${ }^{\mathrm{a}} \mathrm{M}(\%)$ means the mean value of inhibition ratio, ${ }^{* *} \mathrm{p}<0.01$, compared with control group.

\section{Experimental Section}

General Experimental Procedures. Melting point was obtained on an XRC-1 micro melting point apparatus and is uncorrected. Optical rotations were measured with a Jasco P-1020 polarimeter. UV spectra were obtained using a Shimadzu UV-2401A spectrophotometer. A Bruker Tenor 27 spectrophotometer was used for scanning IR spectroscopy

\section{算 Springer}

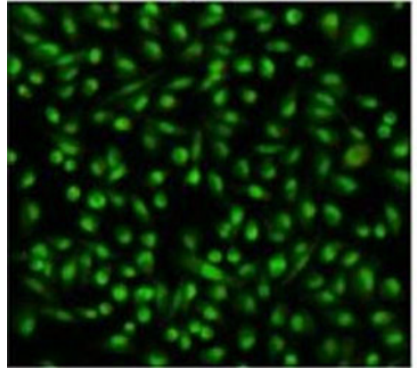

control

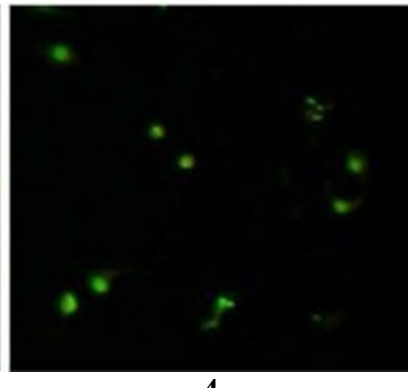

4
Figure 4. Photos of acridine orange staining

with $\mathrm{KBr}$ pellets. 1D and 2D NMR spectra were recorded on Bruker DRX-500 spectrometers. Unless otherwise specified, chemical shifts $(\delta)$ were expressed in ppm with reference to the solvent signals. Mass spectra were performed on an API QSTAR Pulsar i spectrometer. Column chromatography was performed with silica gel (200-300 mesh, Qingdao Marine Chemical, Inc., Qingdao, China). Fractions were monitored by TLC and spots were visualized by heating silica gel plates sprayed with $10 \% \mathrm{H}_{2} \mathrm{SO}_{4}$ in $\mathrm{EtOH}$.

Plant Material. The aerial parts of $M$. sinica were collected in Jinfoshan Mountain of Sichuan Province, China, in August 2008. The specimen was identified by Prof. Yong-Ping Yang and a voucher specimen (Chen $\mathrm{Yu}$-200801) has been deposited at the Institute of Tibetan Plateau Research at Kunming, Kunming Institute of Botany, Chinese Academy of Sciences.

Extraction and Isolation. The dried aerial parts of M. sinica $(8.0 \mathrm{~kg})$ were powdered and extracted with $70 \%$ aqueous $\mathrm{Me}_{2} \mathrm{CO}(15 \mathrm{~L} \times 4)$ for 48 hours at room temperature and filtrated. The filtrate was concentrated and partitioned with EtOAc. The EtOAc portion was subjected to column chromatography over MCI gel eluting with $95 \% \mathrm{EtOH}$ and concentrated in vacuo. The residue $(190 \mathrm{~g})$ was chromatographed on silica gel column eluting with $\mathrm{CHCl}_{3}-\mathrm{MeOH}$ (1:0, $9: 1,8: 2,2: 1, \quad 1: 1$, and $0: 1)$ to afford fractions I-VI. Fraction II (9:1) was repeatedly chromatographed on silica gel (200-300 mesh) and Sephadex LH-20 to yield compounds 1 
(10 mg), 2 (15 mg), 3 (8 mg), 4 (20 mg), 5 (18 mg), 6 (18 mg), and 7 (13 mg).

Musinisin A (1): colorless crystal; mp $150-151{ }^{\circ} \mathrm{C} ;[\alpha]_{\mathrm{D}}^{19.8}-$ 23.95 (c 0.35, MeOH); IR (KBr) $v_{\max } 3490,3347,2985,2901$, $1698,1430,1403,1282,1201,1102,1036,1015,939,637$ $\mathrm{cm}^{-1} ;{ }^{1} \mathrm{H}$ and ${ }^{13} \mathrm{C}$ NMR data see Table 1 ; negative ion ESIMS $m / z 321[\mathrm{M}-\mathrm{H}]^{-}$; HRESIMS $m / z 321.1543$ (calcd for $\left.\mathrm{C}_{14} \mathrm{H}_{25} \mathrm{O}_{8}[\mathrm{M}-\mathrm{H}]^{-}, 321.1549\right)$.

Musinisin B (2): yellow powder; $[\alpha]_{\mathrm{D}}^{19.9}-54.86$ (c 0.14 , $\mathrm{MeOH})$; IR (KBr) $v_{\max } 3546,3476,3396,3277,2979,2914$, 1598, 1462, 1425, 1327, 1130, $1068 \mathrm{~cm}^{-1} ;{ }^{1} \mathrm{H}$ and ${ }^{13} \mathrm{C} \mathrm{NMR}$ data see Table 2; negative ion ESIMS $\mathrm{m} / z 395[\mathrm{M}+\mathrm{Cl}]^{-}$; HRESIMS $m / z 395.1100$ (calcd for $\mathrm{C}_{16} \mathrm{H}_{24} \mathrm{O}_{9} \mathrm{Cl}[\mathrm{M}+\mathrm{Cl}]^{-}$, 395.1108).

Crystallographic data for 1: $\mathrm{C}_{14} \mathrm{H}_{26} \mathrm{O}_{8}, \mathrm{M}=322.36$, orthorhomic, space group $\mathrm{P} 2{ }_{1} 2_{1} 2_{1}, \mathrm{a}=7.2561$ (4) $\AA, \mathrm{b}=9.5748(5) \AA$, $\mathrm{c}=23.2846(14) \AA, \alpha=\beta=\gamma=90^{\circ}, \mathrm{V}=1617.71(16) \AA^{3}, \mathrm{Z}=4$, $\mathrm{d}=1.373 \mathrm{~g} \mathrm{~cm}^{-3}$, crystal size $0.30 \mathrm{~mm} \times 0.52 \mathrm{~mm} \times 0.54$ $\mathrm{mm}$, was used for measurements on a Bruker APEX DUO diffractometer with a graphite monochromator, $\mathrm{Cu} \mathrm{K} \alpha$ radiation. The total number of independent reflections measured was 2753 , of which 2740 were observed $\left(|\mathrm{F}|^{2} \geqslant\right.$ $\left.2 \sigma|\mathrm{F}|^{2}\right)$. Final indices: $R_{1}=0.0363, w R_{2}=0.0920\left(\mathrm{w}=1 / \sigma|\mathrm{F}|^{2}\right)$. The crystal structure of 1 were solved and refined by the direct method SHELX-97 (Sheldrich, G. M. University of Gottingen: Gottingen, Germany, 1985). Crystallographic data for the structure of $\mathbf{1}$ has been deposited in the Cambridge Crystallographic Data Centre (deposition number: CCDC 853392). Copies of this data can be obtained free of charge via www.ccdc.cam.ac.uk/conts/retrieving.html (or from the Cambridge Crystallographic Data Centre, 12, Union Road, Cambridge CB21EZ, UK; fax: (+44) 1223-336-033; or deposit@ ccdc.cam.ac.uk).

Acid Hydrolysis of 2. A solution of $2(5 \mathrm{mg})$ in $2 \mathrm{M} \mathrm{HCl}(3$ $\mathrm{mL}$ ) was heated in a water bath at $70{ }^{\circ} \mathrm{C}$ for $6 \mathrm{~h}$. After cooling, the reaction mixture was neutralized with $\mathrm{NaHCO}_{3}$ and extracted with $\mathrm{CHCl}_{3}$. Through TLC comparison with authentic sample using $\mathrm{CHCl}_{3}-\mathrm{MeOH}$ (8:2) as a developing system, Dglucose was detected in the water layer $\left(R_{f}=0.16\right)$. The aqueous solution was further concentrated to dryness and subjected to a silica gel chromatography eluting with $\mathrm{CHCl}_{3}$ $\mathrm{MeOH}(9: 1)$ to give D-glucose (1 mg), $[\alpha]_{\mathrm{D}}^{18}+40$ (c 0.2 , $\mathrm{MeOH})$. The $\mathrm{CHCl}_{3}$ fraction was further subjected to a silica gel chromatography eluting with petroleum ether-EtOAc $(4: 1)$ to afford the aglycone $(1.2 \mathrm{mg}),[\alpha]_{\mathrm{D}}^{19.9}-4.63(c \mathrm{c} 0.17, \mathrm{MeOH})$.

Antiangiogenesis Bioassay. Stock solutions $(10 \mathrm{mg} / \mathrm{mL})$ of all samples were prepared by dissolving the test compounds in $100 \%$ DMSO. These solutions were diluted in sterile salt water $\left(5 \mathrm{mM} \mathrm{NaCl}, 0.17 \mathrm{mM} \mathrm{KCl}, 0.4 \mathrm{mM} \mathrm{CaCl}_{2}\right.$, and 0.16 $\mathrm{mM} \mathrm{MgSO}_{4}$ ) to obtain solutions with the test compounds dissolved in $0.1 \%$ DMSO. These solutions were aliquot into 96-well plates, and embryos at $24 \mathrm{hpf}$ (hours post fertilization) were also transferred randomly into the above wells. After $24 \mathrm{~h}$ of treatment, the intersegmental vessels of embryos were visualized with green fluorescent protein labeling and endogenous alkaline phosphatase staining. The antiangiogenic activities of compounds were calculated from the inhibition ratio of angiogenesis. PTK787 was used as the positive control.

Antiproliferative Bioassay. A549 lung cancer cells were cultured in RPMI 1640 medium at $37{ }^{\circ} \mathrm{C}$ with $5 \% \mathrm{CO}_{2}$ and $95 \%$ air, supplemented with $10 \%(\mathrm{v} / \mathrm{v})$ bovine calf serum and $80 \mathrm{U} / \mathrm{ml}$ penicillin/streptomycin. The cells were seeded onto 96-well plates and treated with compounds at 3, 10, 30 and $100 \mu \mathrm{g} / \mathrm{mL}$ for $48 \mathrm{~h}$, respectively. Cell viability was determined by MTT (3-(4,5-dimethylthiazol-2-yl)-2,5-diphenyltetrazolium) assay. The light absorption was measured at $570 \mathrm{~nm}$ using Spectra MAX 190 microplate spectrophotometer (GMI Co., USA). Inhibition rate was calculated by the formula:

$$
\text { Inhibition }(\%)=100 \%-\left(\mathrm{OD}_{\text {treatment }}-\mathrm{OD}_{\text {blank }}\right) /\left(\mathrm{OD}_{\text {control }}-\right.
$$
$\left.\mathrm{OD}_{\text {blank }}\right) \times 100 \%$

The cells were incubated with compounds $(100 \mu \mathrm{g} / \mathrm{mL})$ for $48 \mathrm{~h}$, and stained with $0.1 \mathrm{mg} / \mathrm{ml}$ of acridine orange (AO) at room temperature for $5 \mathrm{~min}$. Then the cells were observed and photographed using the fluorescent stereo microscope (Olympus, Japan).

\section{Electronic Supplementary Material}

Supplementary material is available in the online version of this article at $\mathrm{http} / / / \mathrm{dx}$.doi.org/10.1007/s13659-012-0001-8 and is accessible for authorized users.

\section{Acknowledgments}

This project was supported financially by the Bureau of Science and Technology of Kunming City.

Open Access This article is distributed under the terms of the Creative Commons Attribution License which permits any use, distribution, and reproduction in any medium, provided the original author(s) and source are credited.

\section{References}

[1] Yunnan Institute of Botany, Flora Yunnanica; Science Press: Beijing, 1977; Tomus. 1. pp 214-216.

[2] Lin, B. D.; Chen, H. D.; Liu, J.; Zhang, S.; Wu, Y.; Dong, L.; Yue, J. M. Phytochemistry 2010, 71, 1596-1601.

[3] Cai, X. H.; Luo, X. D. Chin. J. Chem. 2007, 25, 986-988.

[4] Cai, X. H.; Du, Z. Z.; Luo, X. D. Helv. Chim. Acta 2007, 90, $1980-1986$

[5] Cai, X. H.; Luo, X. D.; Zhou, J.; Hao, X. J. J. Integ. Plant Biol. 2006, 48, 1126-1128.

[6] Zhang, H. P.; Bao, G. H.; Wang, H. B.; Qin, G. W. Nat. Prod. Res. 2004, 18, 415-419.

[7] Qi, S. H.; Wu, D. G.; Ma, Y. B.; Luo, X. D. J. Asian Nat. Prod. Res. 2003, 5, 215-221.

[8] Qi, S. H.; Chen, L.; Wu, D. G.; Ma, Y. B.; Luo, X. D. Tetrahedron 2003, 59, 4193-4199.

[9] Qi, S. H.; Wu, D. G.; Chen, L.; Ma, Y. B.; Luo, X. D. J. Agr. Food Chem. 2003, 51, 6949-6952.

[10] Itoh, T.; Ninomiya, M.; Nozawa, Y.; Koketsu, M. Bioorg. Med. Chem. 2010, 18, 7052-7057.

[11] Connolly, J. D.; Labbe, C.; Rycroft, S.; Taylor, D. A. H. J. Chem. Soc. Perkin Trans. 1 1979, 2959-2964.

[12] Wu, B.; Li, W.; Lin, W. H.; Gao, H. Y.; Wu, L. J.; Jin, Z. S.

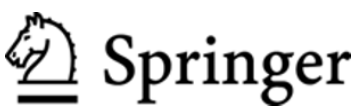


Chin. J. Med. Chem. 2005, 15, 178-179.

[13] Yoshikawa, M.; Shimada, H.; Saka, M.; Yoshizumi, S.; Yamahara, J.; Matsuda, H. Chem. Pharm. Bull. 1997, 45, 464-469.

[14] Cui, B.; Nakamura, M.; Kinjo, J.; Nohara, T. Chem. Pharm. Bull. 1993, 41, 178-182.

[15] IUPAC Nomenclature of Organic Chemistry, Pergamon: New York, 1979, Sections A-H. Recommendation for section A, Spiro hydrocarbons.
[16] Ishikawa, T.; Kondo, K.; Kitajima, J. Chem. Pharm. Bull. 2003, $51,32-39$.

[17] Li, X. L.; Li, Y.; Wang, S. F.; Zhao, Y. L.; Liu, K. C.; Wang, X. M.; Yang, Y. P. J. Nat. Prod. 2009, 72, 1001-1005.

[18] He, Q. X.; Zhu, X. S.; Shi, M.; Zhao, B. X.; Zhao, J.; Zhang, S L.; Miao, J. Y. Bioorg. Med. Chem. 2007, 15, 3889-3895. 